\title{
Progesterone promotes foetal growth in a restricted interspecies gestation (Ovis canadensis $\times$ Ovis aries)
}

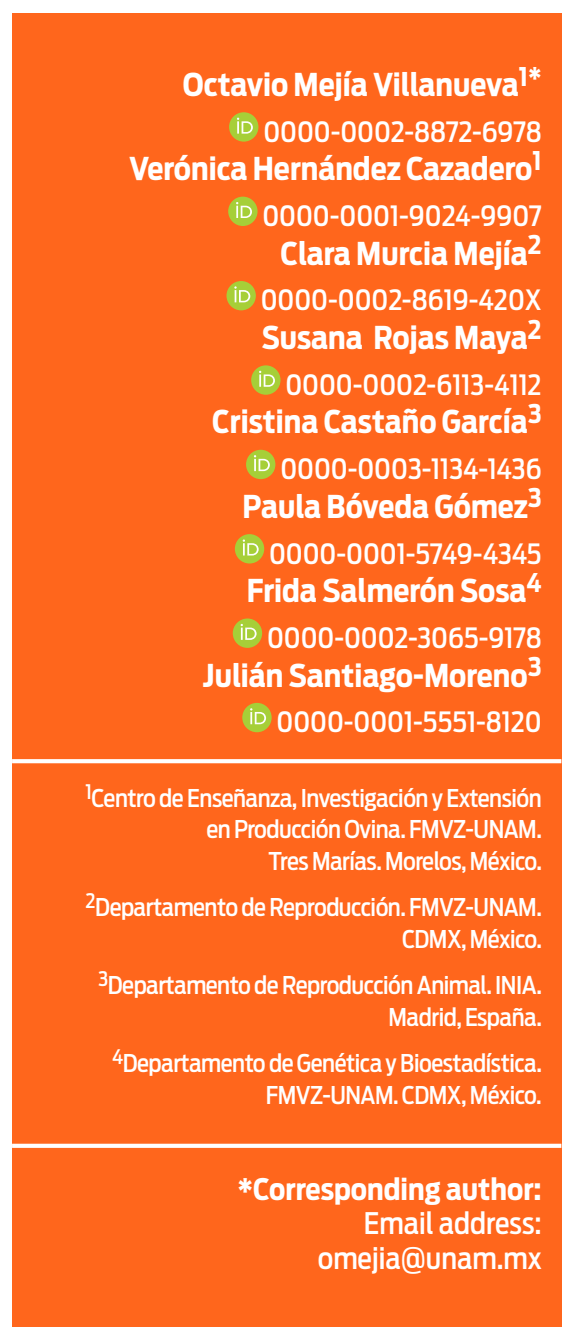

Received: 2017-08-21 Accepted: 2018-07-27

Published: $2018-09-10$

Additional information and declarations can be found on page 9

@) Copyright 2018 Octavio Mejía Villanueva et al. open access $\boldsymbol{\gamma}$

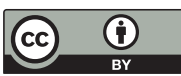

Distributed under Creative Commons CC-BY 4.0

\begin{abstract}
Gestations between bighorn (Ovis canadensis) and domestic sheep ( $O$. aries) can be considered for ex situ conservation of bighorn. In the first experiment, domestic sheep were inseminated with bighorn or domestic semen. Bighorn inseminated sheep showed lower fertility than domestic inseminated sheep ( $40 \%$ vs. $65 \%, p=0.11$ ). Bighorn inseminated sheep had longer gestation periods (152.13 days vs. 146.54 days, $\mathrm{p}<0.001$ ) and lower progesterone levels during the last third. Hybrid lambs weighed less than domestic lambs (2.46 kg vs. $5.10 \mathrm{~kg}, \mathrm{p}<0.001)$. Their placentas were not as long (48.67 cm vs. $72.17 \mathrm{~cm}, \mathrm{p}<0.001)$, were less wide $(17.83 \mathrm{~cm}$ vs. $23.83 \mathrm{~cm}, \mathrm{p}<0.001)$, and the weight of cotyledons was lower $(1.50 \mathrm{~g}$ vs. $3.20 \mathrm{~g}, \mathrm{p}<0.001)$. In the second experiment, hybrid embryos ( 0 . canadensis $\times 0$. aries) were transferred into domestic recipients, and pregnant ewes were divided into the treated group, which had a progesterone daily dose of $25 \mathrm{mg}$ from weeks 7 to 20, and the non treated group. Gestation in domestic sheep that received one hybrid embryo and progesterone reached 152.60 days, which was similar to the 153.33 days $(p=0.51)$ in the non treated sheep. Hybrid offspring of the group treated with progesterone were heavier, $3.41 \mathrm{~kg}$, than the control, $2.21 \mathrm{~kg}(\mathrm{p}<0.001)$, and their placentas were longer ( 71.20 vs. $50.83 \mathrm{~cm}, \mathrm{p}=0.002$ ). Although progesterone levels were lower in domestic females inseminated with bighorn and in the recipients of hybrid embryos, it is possible to establish pregnancies between both species and the birth of viable offspring. The administration of progesterone during gestation increases the length of the placenta and promotes higher birth weights of hybrids.
\end{abstract}

Keywords: foetal growth, progesterone, Ovis canadensis, Ovis aries, interspecies gestation.

\section{Cite this as:}

Mejía Villanueva O, Hernández Cazadero V, Murcia Mejía C, Rojas Maya S, Castaño García C, Bóveda Gómez P, Salmerón Sosa F, Santiago-Moreno J. Progesterone promotes foetal growth in a restricted interspecies gestation (Ovis canadensis $\times$ Ovis aries). Veterinaria México OA. 2018;5(3). doi: 10.22201/fmvz.24486760e.2018.3.507 


\section{Introduction}

Bighorn sheep is one of 14 species of Mexican fauna considered a priority under special protection status by NOM-059-ECOL-2010, 1,2 and only the bighorn sheep of México is still in Appendix II of the Convention on International Trade of Wild Fauna and Flora Endangered Species. ${ }^{3}$ In 1994, Mexican subspecies of the "desert bighorn sheep" were classified by the Red List of Threatened Species of International Union for the Conservation of Nature (IUCN) as "vulnerable" (O. c. mexicana), "endangered" (O. c. cremnobates), and "critically endangered" (O. c. weemsi). ${ }^{4}$ Since 2010, the IUCN reclassified bighorn sheep as of "least concern" 5 because their populations in North America are stable, even though they have increased, mainly in the United States of America, with at least 31,000 desert bighorn sheep in the wild; 6 and 3000 to 4500 with private landowners, mostly in México. However, their distribution is only $4 \%$ of the historical range. ${ }^{6-9}$

Assisted reproduction techniques in wild animal practice as a tool for conservation have been widely discussed by several authors, ${ }^{10-11}$ but there has been little progress in terms of the possible value of interspecies gestations. This is because there are important knowledge voids on the phylogenetic closeness, differences in oestrous cycle and gestation length, differences in placenta formation, and in the immunological gestation that have sparked conflicts. ${ }^{12}$

Interspecies gestations have been achieved in the Ovis genus with the birth of fertile, pure or hybrid lambs, when species have similar chromosome number (mostly $2 n=54$ ), and when the oestrus cycle and gestations are of similar lengths. ${ }^{13-14}$ There are hybrids between Mouflon sheep (O. musimon) and domestic sheep (O. aries), ${ }^{15}$ and between Mouflon and argali sheep (O. argali). ${ }^{16-17}$ Mouflon embryos have been successfully transferred into domestic sheep, ${ }^{18}$ and Armenian red sheep (O. orientalis) lambs have been produced by in vitro fertilization and embryo transfer into domestic females. ${ }^{19}$ These mentioned species have oestrus cycles of 16 days and gestations of 150 days, on average. It has also been possible to produce hybrids between Dall sheep (O. dalli) and bighorn sheep (O. canadensis) ${ }^{20}$ because they share oestrus cycles of approximately 28 days and a gestation period between 175 and 179 days. ${ }^{21-22}$

A recent work on gestations between bighorn and domestic sheep has uncovered that, in these interspecies gestations, there was placental insufficiency, characterized by a significant decrease in the plasma concentration of progesterone and endothelial dysfunction characterized by an increase in plasma levels of vascular endothelial growth factor and placental insulin-like growth factor-1, as well as an overexpression of hypoxia-inducible factor- $1 \alpha^{23}$

This work sought to confirm if the production of hybrids is viable, despite the phylogenetic distance between bighorn and domestic sheep, and if the administering of progesterone throughout these gestations could favour placental development and promote foetal growth.

\section{Materials and methods} Experiment I

\section{Procedures}

To produce hybrids between $O$. canadensis and O. aries, a total of 40 domestic Suffolk sheep between three and four years old, with at least two previous deliv- 
eries and a live weight of about $90 \mathrm{~kg}$, were used in the first experiment. To cover the daily requirements during early pregnancy (first two-thirds), sheep were given $1.75 \mathrm{~kg}$ of dry matter, $3.35 \mathrm{MCal}$ of metabolizable energy and $96 \mathrm{~g}$ of metabolizable protein. During late gestation (last third), sheep were given $2.15 \mathrm{~kg}$ of dry matter, 4.10 MCal of metabolizable energy and $124 \mathrm{~g}$ of metabolizable protein. These requirements were provided by oat hay, alfalfa and commercial feed. Water was available ad libitum throughout the experiment. ${ }^{24}$

Twenty sheep were inseminated with frozen bighorn semen obtained by electroejaculation from two males, one located in the Chapultepec Zoo of México City and the other in the Centro Ecológico de Sonora (Sonora State, México), after fasting and anaesthesia using xylacine (1 mg/kg live weight) and ketamine (4 mg/ $\mathrm{kg})$ and reversed after the process with yohimbine $(0.25 \mathrm{mg} / \mathrm{kg}) \cdot{ }^{25}$ An additional 20 domestic sheep were inseminated with frozen semen collected from two domestic males using an artificial vagina. Previously, the semen of both species was evaluated, diluted with Triladyl (Minitübe) at $37{ }^{\circ} \mathrm{C}$, cooled at $5{ }^{\circ} \mathrm{C}$ for at least two hours, packaged in $0.25-\mathrm{mL}$ straws at a concentration of $70 \times 10^{6}$ and frozen in liquid nitrogen $\left(-196^{\circ} \mathrm{C}\right)$ in 10 minutes. ${ }^{26}$

The ewes were synchronized using vaginal sponges with $20 \mathrm{mg}$ of fluorogestone acetate (FGA) (Chronogest, Intervet) for 12 days and $100 \mathrm{IU}$ of equine chorionic gonadotropin (eCG) (Folligon, Intervet) at the day of removal. Intrauterine insemination was carried out 56 hours later through laparoscopy ${ }^{27}$ after fasting and anesthesia using xylacine $(0.22 \mathrm{mg} / \mathrm{kg}$ live weight) and ketamine $(1 \mathrm{mg} / \mathrm{kg}$ live weight). The diagnosis of gestation was carried out by transrectal ultrasonography with a linear $7.5 \mathrm{MHz}$ transducer at day 30 post-insemination and confirmed by transabdominal ultrasonography with a linear $5 \mathrm{MHz}$ transducer at day $40 .{ }^{28-29}$ Progesterone levels were measured once a week from only six females with single gestations from each group from weeks 6 to 22 of gestation. Blood samples were obtained by venipuncture from the jugular using vacutainer tubes and needles. Samples were centrifuged at $1200 \mathrm{~g}$ for $10 \mathrm{~min}$ to obtain serum, which was kept at $-20{ }^{\circ} \mathrm{C}$ until processing. Progesterone was quantified by a solid-phase radioimmunoassay, which was done in duplicate and in a single assay, using a commercial kit ensuring an intra-assay coefficient of variation $<10 \%$ and an inter-assay coefficient of variation $<15 \%$ (Coat-A -Count Progesterone, Siemens Medical Solutions) and according to the method described by the supplier. The minimum sensitivity of the assay was $0.094 \mathrm{ng} / \mathrm{mL}$, and the intra-assay coefficient of variation was $3.6 \%$. The assay kit has been validated for the ewe. ${ }^{30}$

At parturition, the condition of single gestations was confirmed, the duration was determined, offspring were weighed, and placentas were recovered in order to measure their length and width. Placentas were divided into four quadrants. All of the cotyledons present were counted, and three cotyledons from each quadrant were weighed. ${ }^{31}$

\section{Experiment II}

\section{Procedures}

To evaluate if the administration of exogen progesterone promotes placental development and foetal growth, the second experiment was composed of 30 domestic sheep (with the same characteristics and conditions as Experiment I), from which six 
were embryo donors. Donors were synchronized using vaginal sponges containing $20 \mathrm{mg}$ of FGA during 12 days, and superovulation was induced by intramuscular injection of $180 \mathrm{mg}$ of follicle stimulating hormone (Folltropin, Vetoquinol). The total dosage was divided into two daily administrations for four days, with a decreasing dose pattern (from $40 \mathrm{mg}$ to $10 \mathrm{mg}$ ) across days. The first administration was two days before the removal of the sponge. These sheep were intrauterine inseminated by laparoscopy using two doses of frozen bighorn semen with $70\left(10^{6}\right)$ in each one, 48 hours later. Embryo retrieval was carried out by mid-ventral laparotomy at day seven after insemination. After their evaluation, excellent and good quality morulae and blastocysts ${ }^{32}$ were transferred fresh and individually to 24 recipients, in order to assure that each ewe only gestated a single offspring. Recipients were previously synchronized using vaginal sponges with $20 \mathrm{mg}$ of FGA during 12 days and a $300 \mathrm{IU}$ dose of equine chorionic gonadotropin at the time of their removal. Embryo transfer was done at day seven with the help of an endoscope, in order to expose the uterine horn ipsilateral to the ovary that had the best quality corpus luteum. A small puncture was made on the selected uterine horn, and the embryo previously loaded into a catheter was introduced. ${ }^{33}$ Gestation diagnosis was carried out 40 days after embryo transfer using real-time ultrasonography with a linear $5 \mathrm{MHz}$ transducer, and pregnant ewes were randomly placed into two groups: treated $(n=5$, hybrid embryo $+P 4)$, which received a daily intramuscular dose of $25 \mathrm{mg}(0.5 \mathrm{~mL})$ of a natural progesterone (Progesvit A-E, Dechra-Brovel) from weeks 7 to 20 of gestation, and non treated control $(n=6$, hybrid embryo), which received $0.5 \mathrm{~mL}$ of saline solution in the same schedule as the treated group.

Similar to the first experiment, the progesterone levels were determined each week from weeks 7 to 22 of gestation using a radioimmunoassay, and the duration of gestation was noted. Offspring were weighed at birth, and placentas were recovered to determine their morphometry.

\section{Statistical analyses}

In both experiments, a chi-square test was used to compare the fertility in inseminated or embryo recipient sheep, while a t-test was used for comparing gestation duration, placental morphometry and birth weight. A mixed-model for repeated measures analysis of variance was used to compare the effect of type of gestation and the week of gestation on progesterone concentration: domestic or hybrid and weeks 6 to 22 in Experiment I, and hybrid embryo with progesterone or hybrid embryo without progesterone and weeks 7 to 22 in Experiment II. For the test, the type of gestation and week of gestation were considered as fixed effects, while sheep were considered as a random effect. ${ }^{34}$

\section{Ethical standards}

The authors declare that the experimental protocol was approved by the Internal Committee for Care and Use of the Animals (CICUA, FMVZ-UNAM) and according to Mexican legislation. 
Table 1. Placental morphometry grouped by gestation type

\begin{tabular}{|c|c|c|c|c|}
\hline Gestation type & $\begin{array}{c}\text { Placenta length }(\mathrm{cm}) \\
(\text { mean } \pm \mathrm{SE})\end{array}$ & $\begin{array}{l}\text { Placenta width }(\mathrm{cm}) \\
\quad(\text { mean } \pm \mathrm{SE})\end{array}$ & $\begin{array}{c}\text { Number of cotyledons } \\
\text { (mean } \pm \mathrm{SE} \text { ) }\end{array}$ & $\begin{array}{l}\text { Cotyledon weight (g) } \\
(\text { mean } \pm \mathrm{SE})\end{array}$ \\
\hline $\begin{array}{l}\text { Intraspecies or } \\
\text { domestic }(n=6)\end{array}$ & $72.17 \pm 1.35^{\mathrm{a}}$ & $23.83 \pm 1.07^{a}$ & $54.67 \pm 2.02^{\mathrm{a}}$ & $3.20 \pm 0.27^{a}$ \\
\hline \multirow{2}{*}{$\begin{array}{l}\text { Interspecies or } \\
\text { hybrid }(n=6)\end{array}$} & $48.67 \pm 2.48^{b}$ & $17.83 \pm 0.47^{b}$ & $53.50 \pm 2.23^{a}$ & $1.50 \pm 0.13^{b}$ \\
\hline & $\begin{array}{c}(t(10)=8.30 \\
p<0.001\end{array}$ & $\begin{array}{c}(t(10)=5.09 \\
p<0.001\end{array}$ & $(t(10)=0.38, p=0.70$ & $\begin{array}{c}(\mathrm{t}(10)=5.46 \\
\mathrm{p}<0.001\end{array}$ \\
\hline
\end{tabular}

a,b Within variables, values with different letters are statistically differents.

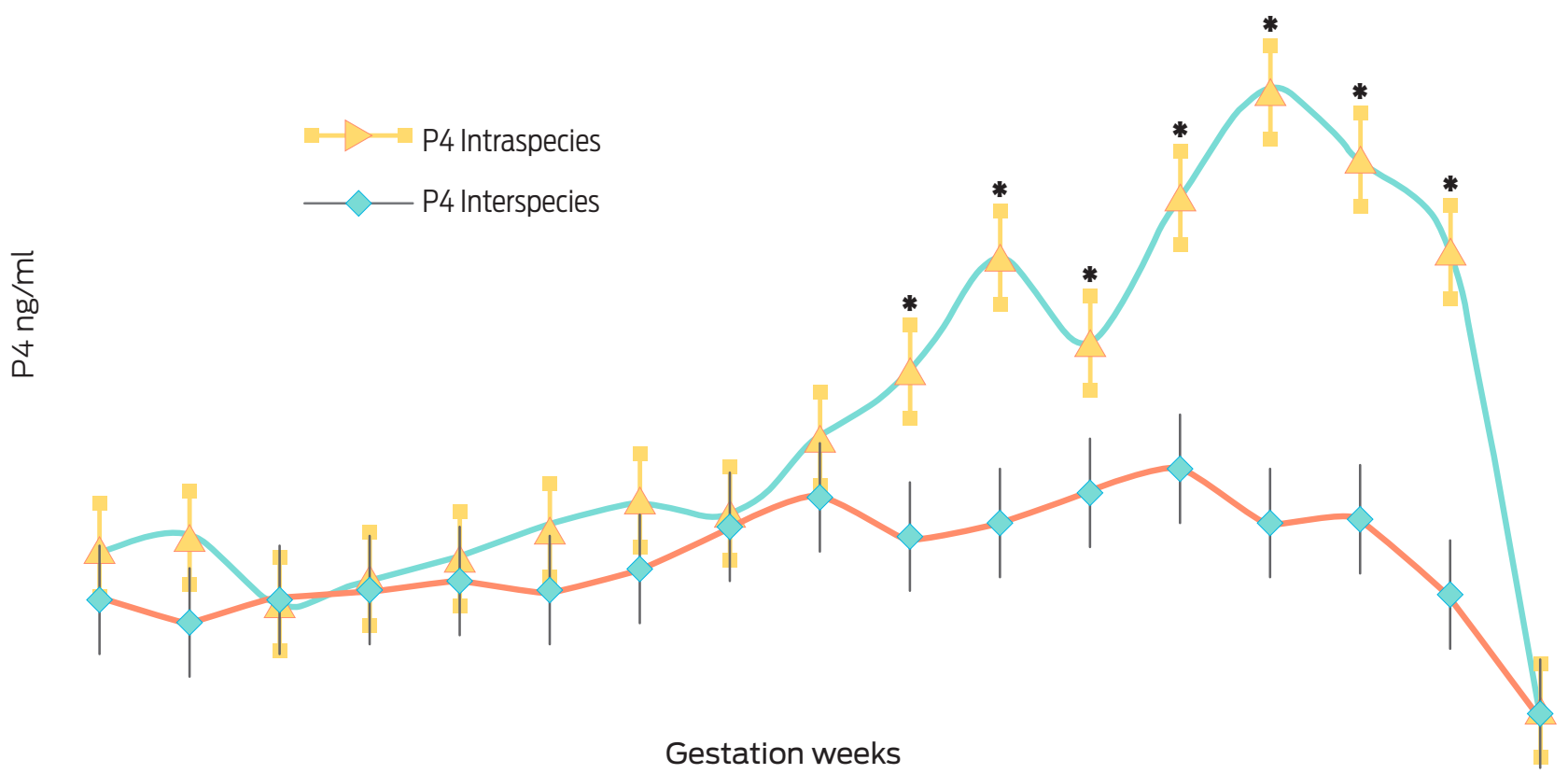

Figure 1. Progesterone $(\mathrm{ng} / \mathrm{mL})$ in interspecies gestations (O. c. mexicana $\times 0$. aries, $\mathrm{n}=6)$ and intraspecies gestations $(O$. aries $\times 0$. aries, $\mathrm{n}=6)$. *Statistically different values $(\mathrm{p}<0.01)$.

\section{Results and discussion}

\section{Experiment I}

Domestic sheep inseminated with frozen bighorn semen had reduced fertility, 40\% (8/20), when compared to those inseminated with domestic semen, 65\% (13/20), $\left(x^{2}(1)=2.50, p=0.11\right)$. The duration of gestation in domestic sheep inseminated with bighorn semen was greater, $152.13 \pm 0.22$ days, than in domestic sheep inseminated with domestic semen, $146.54 \pm 0.21$ days $(t(19)=-17.04, p<0.001)$. Hybrid offspring (O. c. mexicana $\times$ O. aries) weighed less at birth, $2.46 \pm 0.09 \mathrm{~kg}$, than domestic offspring, $5.10 \pm 0.22 \mathrm{~kg},(\mathrm{t}(10)=10.83, \mathrm{p}<0.001)$. Table 1 shows the morphometry of the placentas that were recovered at birth grouped by the type of gestation.

Figure 1 shows the serum progesterone levels determined between weeks 6 and 22 of gestation. In general, progesterone levels were lower during the final third of interspecies gestations (O. c. mexicana $\times O$. aries) when compared to the levels determined from domestic sheep gestations (O. aries $\times 0$. aries), $(F(33$, 170) =9.35, $p<0.001$, partial $\eta^{2}=0.64$ ). 
Table 2. Placental morphometry by group

\begin{tabular}{|c|c|c|c|c|}
\hline Group & $\begin{array}{l}\text { Placenta length }(\mathrm{cm}) \\
(\text { mean } \pm \mathrm{SE})\end{array}$ & $\begin{array}{l}\text { Placenta width }(\mathrm{cm}) \\
\quad(\text { mean } \pm \mathrm{SE})\end{array}$ & $\begin{array}{c}\text { Number of cotyledons } \\
\text { (mean } \pm \text { SE) }\end{array}$ & $\begin{array}{c}\text { Cotyledon weight (g) } \\
\text { (mean } \pm \mathrm{SE})\end{array}$ \\
\hline $\begin{array}{l}\text { Hybrid embryo }+ \text { P4 } \\
\quad(n=5)\end{array}$ & $71.20 \pm 3.03^{a}$ & $19.44 \pm 1.13^{a}$ & $54.60 \pm 2.61^{a}$ & $1.70 \pm 0.27^{a}$ \\
\hline \multirow{2}{*}{$\begin{array}{l}\text { Hybrid embryo } \\
\qquad(n=6)\end{array}$} & $50.83 \pm 3.33^{b}$ & $18.66 \pm 0.76^{a}$ & $56.83 \pm 6.68^{a}$ & $1.33 \pm 0.24^{\mathrm{a}}$ \\
\hline & $(t(9)=4.43, p=0.002$ & $\begin{array}{l}(t(9)=0.58 \\
P=0.57\end{array}$ & $(t(9)=-0.28, p=0.78$ & $\begin{array}{l}(\mathrm{t}(9)=0.98 \\
\mathrm{P}=0.35\end{array}$ \\
\hline
\end{tabular}

a,b Within variables, values with different letters are statistically different.

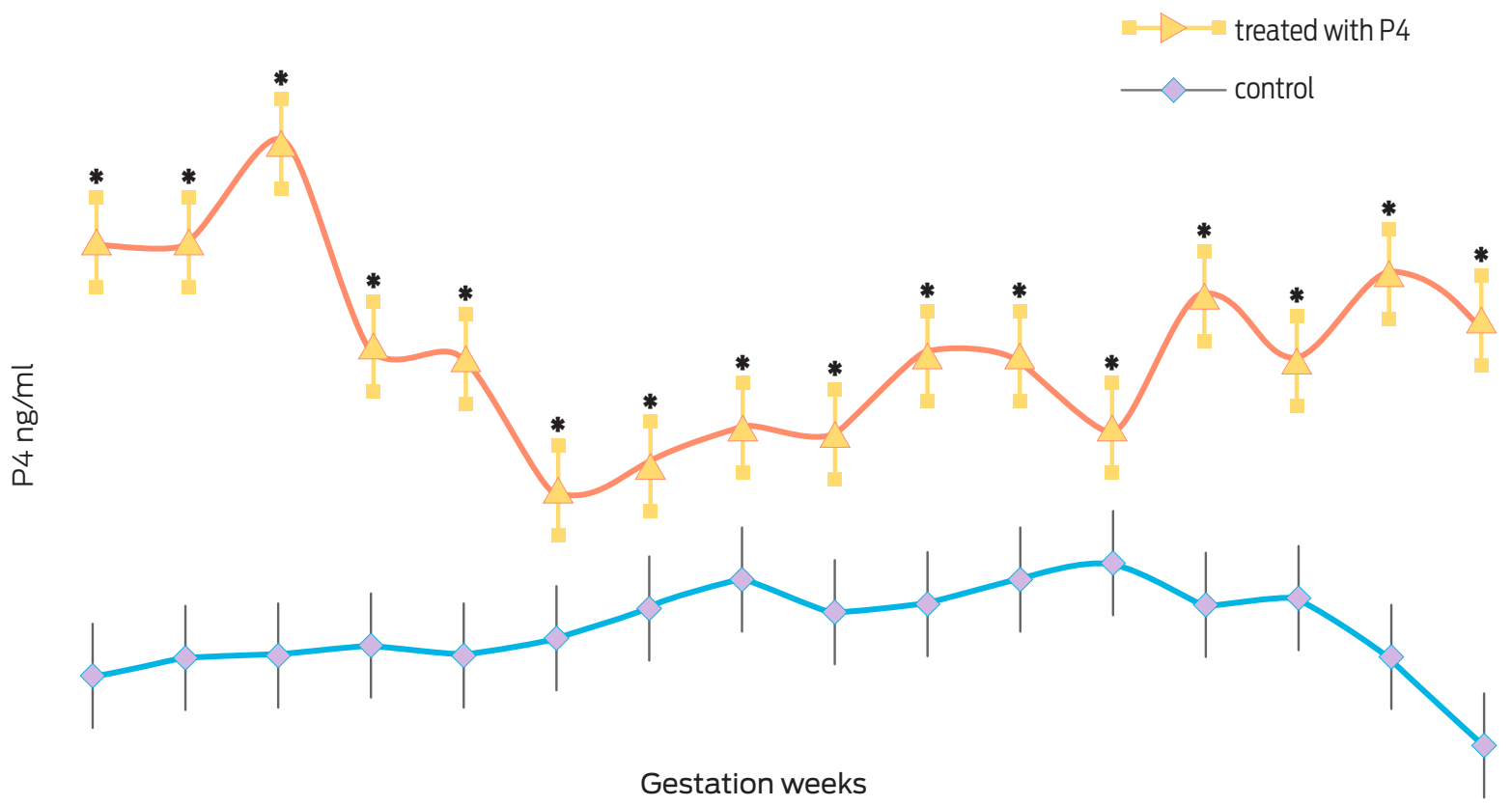

Figure 2. Progesterone $(\mathrm{ng} / \mathrm{mL})$ in interspecies gestations (O. c. mexicana $\times$ O. aries) treated $(n=5)$ or control $(n=6)$. *Statistically different values $(p<0.01)$.

\section{Experiment II}

The duration of gestation in domestic sheep that received one hybrid embryo (O. c. mexicana $\times$ 0 . aries) and progesterone treatment reached $152.60 \pm 0.51$ days, which is similar to the $153.33 \pm 0.88$ days $(t(9)=-0.68, p=0.51)$ in the non treated group. Offspring of the group treated with progesterone had higher birth weights, $3.41 \pm 0.20 \mathrm{~kg}$, than the control, $2.21 \pm 0.10 \mathrm{~kg}$, $(t(9)=5.46, p<0.001)$. Table 2 shows the morphometry of the placentas recovered at birth by group.

Figure 2 shows the serum progesterone levels determined between weeks 7 and 22 of gestation. Progesterone levels were significantly higher during all gestation $(F(31,144)=14.26$, $p<0.001$, partial $\eta^{2}=0.75$ ) in females with an interspecies gestation (O. c. mexicana $\times$ $O$. aries) and treated with exogenous progesterone.

The establishment and development of assisted reproduction techniques in bighorn sheep in México have been considered. In a previous work, bighorn sheep embryos (O. c. mexicana) were transferred into two domestic sheep ewes (O. aries) and two F1 hybrids (O. c. mexicana $\times$ $O$. aries), from which none of the domestic ewes became pregnant, and one of the hybrid recipients lost its pregnancy of two bighorn offspring at day $156 .{ }^{35}$ 
The value of hybrids in ex situ conservation was demonstrated with the rescue project for wild ibex goats (Capra pyrenaica pyrenaica), which recently became extinct in Spain. In these studies, the transfer of 53 ibex embryos into domestic goats (C. hircus) produced only two offspring. The authors attributed the loss of the majority of the gestations to placental incompatibility or immunological rejection. ${ }^{36-37}$ Later, ibex embryos were transferred into hybrid first (F1) and second (F2) filial generations (C. p. pyrenaica $\times$ C. hircus), from which three Ibex offspring were born, one from an F1 hybrid and two from F2 hybrids. ${ }^{38}$ Finally, after several attempts with an important number of cloned embryos transferred into domestic and hybrid goats, the gestation of an ibex in a hybrid recipient and the birth of a live ibex offspring was achieved, although it died due to respiratory problems minutes after being born. ${ }^{39}$

Despite the differences in the length of the oestrous cycle and gestation, and the lower fertility of the domestic sheep inseminated with frozen semen of bighorn, it is possible to produce embryos, gestations and viable hybrids between these not very closely related species. ${ }^{23,40}$ The duration of gestation can be modified by different factors, and the foetal genotype has a very significant effect on the gestation period, because within this genome, the paternal component is the most important. ${ }^{41}$ In hybrids between donkey and horse (mules), the gestation period is closer to the father's species than to that of the mother. ${ }^{42}$ Similarly, regarding the gestations of hybrids between bighorn and domestic sheep, the paternal component of the bighorn sheep that has a gestation period of approximately 175 days $^{21}$ significantly increases the normal gestation period of domestic sheep, from 146 days to 152 days (on average), like the results obtained in these two experiments and in a previous work. ${ }^{23}$

From a physiological perspective, an inadequate placental vascularization and size throughout pregnancy causes reduced intrauterine foetal growth and the birth of small offspring. ${ }^{43}$ This condition is known as intrauterine growth restriction (IUGR), and it has been extensively studied in women with pre-eclampsia and new-born infants with an evident delay in their growth. ${ }^{44}$ Animal models that cause IUGR decrease blood flow between the placenta and foetus by ligature of one of the foetal umbilical arteries ${ }^{45}$ or by limiting the implant sites between the endometrium and the placenta by partial removal of endometrial caruncles. ${ }^{46}$ Placentas and offspring that showed restricted vascularization and reduced intrauterine growth, such as in those coming from numerous litters, have also been studied. ${ }^{47-48}$ Other models restrict feed or over feed pregnant females in order to evaluate the effects on placental, cotyledon and foetal development, as well as the concentrations of various hormones, amino acids and essential metabolites. ${ }^{49-51}$

The proper development of the placenta is critical for determining the availability of nutrients in the development of the foetus and regulation of gas exchange or removal of waste products. The placental exchange efficiency is also affected by morphology, since it has great plasticity and adaptation to situations that cause stress. ${ }^{31,43}$ Since the maintenance of gestation depends greatly on the intense growth and formation of new blood vessels (angiogenesis) in the placenta, which in turn has a direct association with uterine and umbilical blood flow, the foetal weight and placental size are a consequence of these interactions. ${ }^{52-53}$ Several studies have demonstrated the existence of a positive direct relationship between the amount of uterine and umbilical blood flow and the growth and weight of 
placentomes. The greater the blood flow, the heavier is the weight; therefore, the importance of placental circulation resides in its close relationship with foetal and placental weights. An increase in uterine vascular resistance has been clinically shown to have an effect on placental vascular and placentome development, decreasing the nutrient exchange capacity, which in turn has a negative effect on foetal growth and birth weight. ${ }^{54-55}$ This is similar to the results obtained with the interspecies gestations between bighorn and domestic sheep that are not treated with exogenous progesterone.

Progesterone is a hormone that is directly related to gestation, due to its multiple effects on the differentiation of the endometrial stroma, the control of the secretion of molecules that provide nutrition to the embryo at early stages, and the uterine secretion of local immunomodulating molecules, among others, that determine the gestation success or failure. ${ }^{56-57}$ With regard to domestic sheep, progesterone is produced at the beginning of gestation only by the corpus luteum, but starting from day 50 of gestation, the placenta produces higher levels. ${ }^{58-59}$ There is evidence in different species, including sheep, where both embryo survival and development rhythm depend on the concentration of progesterone present during the first weeks of life. ${ }^{60-64}$ In addition, the lamb birth weight has been positively correlated with the progesterone concentrations from weeks 9 to 19 of gestation. ${ }^{65}$ Higher levels of progesterone during all of gestation allow the mobilization of larger quantities of fatty acids and glucose from reserves into the maternal circulation, and similarly, greater development of the placenta produces greater placental lactogen and other hormones with mitogenic activity favouring the intrauterine growth of the foetus. ${ }^{51,66}$

When comparing placental development in the second experiment of this work, it becomes noticeable that placentas from O. c. mexicana $\times 0$. aries interspecies gestations treated with progesterone have greater lengths, similar to that of intraspecies $O$. aries $\times O$. aries gestations from the first experiment. This result could explain why the birth weight of hybrid offspring from the group treated with progesterone was also higher in relation to the hybrid offspring weight of the non treated control group. These results also suggest that progesterone could have a major effect on foetal growth in restricted gestations.

\section{Conclusions}

Although the insemination of domestic sheep with bighorn sheep semen causes reduced fertility and lighter offspring birth weight, the production of hybrids is possible. Since foetal genotype has an effect on the duration of gestation, the use of hybrid females could be proposed as bighorn sheep embryo recipients. This type of interspecies gestations, $\mathrm{O}$. canadensis $\times O$. aries, could be considered as a restricted intrauterine growth model that could provide information regarding both domestic and wild animals. Similarly, the evaluation of simple treatments, such as the administration of progesterone to promote placental development and higher weights at birth, which are events related to placental vascularization and in turn with intrauterine foetal growth, could contribute to the development of assisted reproduction techniques for the conservation of wild species that are threatened, as well as to the study of an issue relevant to animal health and wellbeing. 


\section{Acknowledgements}

The authors wish to thank to PAPIIT-DGAPA of UNAM for financial support given throughout the Project IT201512. Corresponding author wishes to thank to PASPA-DGAPA-UNAM for the economical assistance during the sabbatical leave at INIA.

\section{Conflicts of interest}

The authors have not conflicts of interest to declare.

\section{Author contributions}

$\mathrm{OM}$. Directed the research, performed fieldwork, analysed the information, performed meta-analysis of statistical procedures for APA format and wrote the manuscript. VH. Performed fieldwork, laboratory work and analysed the information. CM. Lead and performed laboratory work. SR. Performed laboratory work and analysed the information. CC. Performed statistical analyses and wrote the manuscript. PBP. Analysed information and wrote the manuscript. FS. Performed metJSM. Performed statistical analyses and wrote the manuscript.

\section{References}

1. INE/Semarnat. Instituto Nacional de Ecología y Secretaría del Medio Ambiente y Recursos Naturales. Norma Oficial Mexicana (NOM-059-ECOL-2010) [internet]. 2010. Available in: http://www.biblioteca.semarnat.gob.mx/janium/Documentos/Ciga/agenda/OFsr/DO2454.pdf

2. Secretaría de Gobernación. Proyecto de modificación del Anexo normativo III, lista de especies en riesgo de la Norma Oficial Mexicana (NOM-059-ECOL-2010) [internet]. 2015. Available in: http://www.dof.gob.mx/

3. CITES. Convención sobre el comercio internacional de especies amenazadas de fauna y flora silvestres. [internet]. 2017. Available in: http://www.cites.org/sites/ default/files/esp/app/2017/S-Appendices-2017-04-04.pdf.

4. IUCN version 2.3. The IUCN red list of threatened species [internet]. 1994. Available in: http://www.iucnredlist.org/technical-documents/categories-and-criteria

5. IUCN version 3.1. The IUCN red list of threatened species [internet]. 2010. Available in: http://www.iucnredlist.org/technical-documents/categories-and-criteria

6. Jorgensen M. Desert bighorn sheep: wilderness icon. In: Jorgensen M, Young J, Palmer A, editors. San Diego, CA (USA): Sunbelt Publications, 2015.

7. Ceballos G, Oliva G. Los mamíferos silvestres de México. DF (MX): CONABIO-Fondo de Cultura Económica, 2005.

8. González F, Tarango L, Cantú C, Uvalle J, Marmolejo J, Ríos C. Estudio poblacional y de distribución del borrego cimarrón (Ovis canadensis mexicana, Merriam, 1901) en el estado de Sonora. Rev Mex Cien For. 2011;2(4):1-15.

9. Lee R, Segundo J. Status report on desert bighorn sheep in various states in México. Desert bighorn Council Transactions. 2011;51:80-4.

10. Wildt $\mathrm{D}$, Monfort S, Donoghue A, Johnston L, Howard J. Embryogenesis in conservation biology-or, how to make an endangered species embryo. Theriogenology. 1992;37:161-84.

11. Lasley B, Loskutoff N, Andersen G. The limitation of conventional breeding programs and the need and promise of assisted reproduction in non-domestic species. Theriogenology. 1994;41:119-32. 
12. Zeh D, Zeh J. Reproductive mode and especiation: the viviparity-driven conflict hypothesis. Bioassay. 2000;22:938-46.

13. Hoffman R, Woolf A. G-Band Patterns as chromosomal markers, and the interpretation of chromosomal evolution in wild sheep (Ovis). Experientia. 1973;29:117-9.

14. Delgadillo A, Mejía O, Berruecos J, Vásquez C. Estudio morfológico de los cromosomas del borrego cimarrón (Ovis canadensis), Tabasco o Pelibuey (Ovis aries) y su cruza. Vet Méx. 2003;34:27-37.

15. Garde J, Perez S, Aguado M, Ayllon E, Garrido D, Montoro V. Live birth of hybrid (O. musimon $\times$ O. aries) lambs following intrauterine insemination in domestic sheep with mouflon semen obtained 40 hours postmortem. Theriogenology. 1995;43:218.

16. Bunch T, Cox L. Argali-mouflons-Gambling with genes. Wild Sheep Int. 1980;2:9-12.

17. Bunch T, Workman G. Hybridization of desert bighorn and Argali-Mouflon wild sheep. Desert bighorn Counc Trans. 1988;32:16-18.

18. Santiago-Moreno J, González-Bulnes A, Gomez-Brunet Y, Cocero M, Del Campo A, García-García R, et al. Procedure for successful interspecific embryo transfer from mouflon (Ovis gmelini musimon) to spanish Merino sheep (Ovis aries). J Zoo Wildl Med. 2001;32(3):336-41.

19. Coonrod S, Flores-Foxworth G, Moreno J, Westhusin M, Byrd S, Kramer D. Birth of Armenian red sheep (Ovis orientalis) lambs to domestic sheep (Ovis aries) following interspecific transfer of IVM-IVF derived embryos. Theriogenology. 1994;41:182.

20. Hoefs M, Nowlan U. Hybridization of thin-horn and big-horn sheep, Ovis dalli $\times$ Ovis canadensis. Canadian Field-Naturalist. 1997;111(4):647-8.

21. Turner J, Hansen C. The desert Bighorn. It's life, history, ecology and management. In: Monson G, Sumner L, editors. Arizona (USA): The University of Arizona Press, 1980.

22. Schoenecker K, Lynda R, Kirkpatrick J. Comparison of free fecal metabolites for pregnancy detection used with single sampling in bighorn sheep (Ovis canadensis). J Wildl Dis. 2004;40(2):273-81.

23. Chávez-García A, Vázquez-Martínez E, Murcia C, Rodríguez A, Cerbón M, Mejía O. Phenotypic and molecular characterization of intrauterine fetal growth restriction in interspecies sheep pregnancy. J Anim Sci. 2015;93(10):4692-701.

24. National Research Council. Nutrient requirements of small ruminants. Washington, DC (USA): The National Academic Press, 2007.

25. Festa-Bianchet $M$, Jorgenson J. Use of xylazine and ketamine to immobilize bighorn sheep in Alberta. J Wildl Manage. 1985;49:162-5.

26. Mejía M, Medrano A, González-Rebeles C, Mejía O. Capacitation status of frozen-thawed spermatozoa from wild ruminants. Eur J Wildl Res. 2009;55(1):1-6.

27. De Graaf S, Evans G, Maxwell W, Cran D, O'brien J. Birth of offspring of pre-determined sex after artificial insemination of frozen-thawed, sex-sorted and refrozen-thawed ram spermatozoa. Theriogenology. 2007;67(2):391-8.

28. Romano J, Christians C. Early pregnancy diagnosis by transrectal ultrasonography in ewes. Small Rum Res. 2008;77(1):51-7. 
29. Jones A, Gately R, McFadden K, Zinn S, Govini K, Reed S. Transabdominal ultrasound for detection of pregnancy, fetal, and placental landmarks, and fetal age before day 45 of gestation in the sheep. Theriogenology. 2016;85(5):939-45.

30. Padmanabhan V, Evans N, Dahl G, McFadden K, Mauger D, Karsch F. Evidence for short or ultrashort loop negative feedback of gonadotropin-releasing hormone secretion. Neuroendocrinology. 1995;62:248-58.

31. Parraguez V, Atlagich M, Díaz R, Cepeda R, González C, De los Reyes M, et al. Ovine placenta at high altitudes: comparison of animals with different times of adaptation to hypoxic environment. Anim Reprod Sci. 2006;95:151-7.

32. Bó G, Mapletoft R. Evaluation and classification of bovine embryos. Anim Reprod. 2013;10(3):344-8.

33. Cervantes J, Juárez L, Mejía $\mathrm{O}$, Berruecos $\mathrm{M}$, Vera $\mathrm{H}$, Valencia J. Use of fluorogestone acetate after breeding to reduce the effect of premature luteal regression in dairy goats when superovulation is induced with FSH. Anim Reprod Sci. 2007;97;47-54.

34. Litell $R$, Henry $P$, Ammerman C. Statistical analysis of repeated measures data using SAS procedures. J Anim Sci. 1998;76:1216-31.

35. Mejía $O$, Gual F, Núñez J, Pérez M, Palma M. Perspectivas en zoología mexicana. In: Sánchez A, Hidalgo-Mihart M, Arriaga-Weiss S, Contreras-Sánchez W, compiladores. Tabasco (MX): Fondo Editorial UJAT, 2008.

36. Fernández-Arias A, Folch J, Alabart J, Ramon J. Successful interspecific embryo transfer between spanish ibex (Capra pyrenaica) and domestic goat (Capra hircus) using micro-osmotic pumps for FSH administration. Theriogenology. $1999^{\mathrm{a}} ; 45: 247$.

37. Fernández-Arias A, Alabart J, Folch J, Beckers J. Interespecies pregnancy of spanish ibex (Capra pyrenaica) fetus in domestic goat (Capra hircus) recipients induces abnormally high plasmatic levels of pregnancy-associated glycoprotein. Theriogenology. 1999b;51(8):1419-30.

38. Fernández-Arias A, Roche A, Alberio R, Alabart J, Folch J. Use of hybrids as recipients in interspecies embryo transfer in the capra genus. Theriogenology. 2001;55:383.

39. Folch J, Cocero M, Chesné P, Alabart J, Domínguez V, Cognié Y, et al. First birth of an animal from an extinct subspecies (Capra pyrenaica pyrenaica) by cloning. Theriogenology. 2009;71(6):1026-34.

40. Palma-Irizarry $M$, Damián-Matsumura $P$, Betancourt $M$, Perales $G$, Lagunas-Martínez A, Mejía $\mathrm{O}$, et al. Identification of novel variants of Interferon-tau gene in bighorn sheep (Ovis canadensis mexicana), pelibuey sheep (Ovis aries) and its expression in hybrid blastocysts (Ovis canadensis $\times$ Ovis aries). Canadian J Anim Sci. 2012;92(3):275-83.

41. Challis J. The placental clock: A review. Trophoblast Res. 1998;12:361-374.

42. Boeta $M$, Zarco L. Endocrine alterations around the time of abortion in mares impregnated with donkey or horse semen. Anim Reprod Sci. 2010;121(1-2):124-30.

43. Fowden A, Ward J, Wooding F, Forhead A. Developmental programming of the ovine placenta. Reprod Dom Rum. 2010;67(Suppl vil):41-57.

44. Ahmed A, Dunk C, Ahmad S, Khaliq A. Regulation of placental vascular endothelial growth factor (VEGF) and placenta growth factor (PIGF) and soluble Flt- 1 by oxygen. Placenta. 2000;(21 Suppl A):S16-24. 
45. Miller S, Loose J, Jenkin G, Wallace E. The effects of sildenafil citrate (Viagra) on uterine blood flow and well being in the intrauterine growth restricted fetus. Am J Obstet Gynecol. 2009;200(102):1-7.

46. Owens J, Kind K, Carbone F, Robinson J, Owens P. Circulating insulin-like growth factors-I and $-I I$ and substrates in fetal sheep following restriction of placental growth. J Endocrinol. 1994;140(1):5-13.

47. Gootwine E, Spencer T, Bazer F. Litter-size-dependent intrauterine growth restriction in sheep. Anim Prod Sci. 2007;1:547-64.

48. Lassala A, Bazer F, Cudd T, Datta S, Keisler D, Carey M, et al. Parenteral administration of L-arginine enhances fetal survival and growth in sheep carrying multiple fetuses. J Nutr. 2011;141:849-55.

49. Quigley S, Kleeman D, Walker S, Speck P, Rudiger S, Natrass $G$, et al. Effect of variable long-term maternal feed allowance on the development of the ovine placenta and fetus. Placenta. 2008;29:539-48.

50. Lassala A, Bazer F, Cudd T, Li P, Li X, Satterfield C, et al. Intravenous administration of $\mathrm{L}$-citrulline to pregnant ewes is more effective than $\mathrm{L}$-arginine for increasing arginine availability in the fetus. J Nutr. 2009;139:660-5.

51. Satterfield C, Bazer F, Spencer T, Wu G. Sildenafil citrate treatment enhances amino acid availability in the conceptus and fetal growth in an ovine model of intrauterine growth restriction. J Nutr. 2010;40:251-8.

52. Reynolds L, Borowicz P, Vonnahme K, Johnson M, Grazul-Bilska A, Redmer, D. Placental angiogenesis in sheep models of compromised pregnancy. J Physiological. Topical Review. 2005; 565(1):43-58.

53. Girling J, Lederman F, Walter L, Rogers A. Progesterone but not estrogen, stimulates vessel maturation in the mouse endometrium. J Endocrinol. 2007; 148(11):5433-41.

54. Reynolds L, Redmer D. Angiogenesis in the placenta. Biol Reprod. 2001;64:1033-40.

55. Redmer D, Wallace J, Reynolds L. Effects of nutrient intake during pregnancy on fetal and placental growth and vascular development. Dom Anim Endocrinol. 2004;27:199-217.

56. Manalu W, Summaryadi Y. Maternal serum progesterone concentration during pregnancy and lamb birth weight at parturition in Javanese thin-tail ewes with different litter sizes. Small Rum Res. 1998;30:163-9.

57. Davies S, Richardson M, Anthony F, Mukhtar D, Cameron T. Progesterone inhibits insulin like growth factor binding protein-1 (IGFBP-1) production by explants of the fallopian tube. Molec Human Reprod. 2004;10(12):935-9.

58. Su X, Carey Y, Rose C. Ontogeny of StAR and ACTH-R genes in ovine placenta. Placenta. 2004;25:658-63.

59. Lea G, Wooding P, Stewart I, Hannah T, Morton S, Wallace K, et al. The expression of ovine placental lactogen, StAR and progesterone-associated steroidogenic enzymes in placenta of overnourished growing adolescent ewes. Reprod Res. 2007;133:785-96.

60. Ashworth C, Bazer F. Changes in ovine conceptus and function endometrial following asynchronous embryo transfer or administration of progesterone. Biol Reprod. 1989;40:425-33. 
61. Nephew K, McClure K, Ott T, Budois D, Bazer F, Pope W. Relationship between variation in conceptus development and differences in estrous cycle duration in ewes. Biol Reprod. 1991;44:536-9.

62. Garret J, Geisert R, Zavy M, Morgan G. Evidence for maternal regulation of early conceptus growth and development in beef cattle. J Reprod Fert. 1998;84:437-46.

63. Crosby T, O'Donnell A, O'Doherty J, Quinn J, Evans A. Effects of exogenous progesterone on gestation length, foetal survival and colostrum yield in ewes. Theriogenology. 2005;64:1121-29.

64. Mann G, Fray M, Lamming G. Effects of time of progesterone supplementation on embryo development and interferon-tau production in the cow. Vet J. 2006;171(3):500-3.

65. Ranilla M, Sulon J, Mantecón A, Beckers J, Carro M. Plasma pregnancy-associated glycoprotein and progesterone concentrations in pregnant Assaf ewes carrying single and twin lambs. Small Rum Res. 1997;24(2):125-31.

66. Grazul-Bilska A, Johnson M, Borowicz P, Bilski J, Cymbaluk T, Norberg S, et al. Placental development during early pregnancy in sheep: effects of embryo origin on vascularization. Reproduction. 2014;147:639-48. 